\title{
DE LA INDIFERENCIA PÚBLICA A LA PROTECCIÓN DE LOS AUTORES E INTÉRPRETES DE LAS PRODUCCIONES DE CINE EN COLOMBIA, A PROPÓSITO DE LA LEY PEPE SÁNCHEZ DE $2017^{*}$
}

\section{FROM THE PUBLIC INDIFFERENCE TO THE PROTECTION OF FILM PRODUCTION AUTHORS AND INTERPRETERS IN COLOMBIA: IN RESPECT OF THE 2017 'PEPE SANCHEZ’ ACT}

Germán Dario Flórez Acero a

DOI: https://doi.org/10.11144/Javeriana.vj136.dipp

Universidad Católica de Colombia, Colombia

Universidad Nacional de Colombia, Colombia

Firma 1493 Consultoria legal internacional, Colombia

gdflorez@ucatolica.edu.co

ORCID: http://orcid.org/0000-0002-0850-1307

Fecha de recepción: 08 Junio 2017

Fecha de aprobación: 12 Julio 2017

Fecha de publicación: 30 Mayo 2018

Sebastián Salazar Castillo

Rincón Cuéllar \& Asociados, Colombia

Universidad Nacional de Colombia, Colombia

ORCID: http://orcid.org/0000-0001-8029-9177

Carlos Ernesto Acevedo Pérez

Universidad Nacional de Colombia, Colombia

ORCID: http://orcid.org/0000-0001-5124-1304

\section{Resumen:}

Este artículo de investigación busca profundizar en los antecedentes que dieron origen a la protección de las obras cinematográficas en Colombia. Igualmente, el artículo reflexiona sobre cómo la evolución legislativa en materia de cine, fue de la mano del crecimiento de la industria en el país. También se explora cuál es el alcance de los derechos que tiene cada uno de los autores e intérpretes de las obras cinematográficas en el país. Igualmente se estudia la evolución de sus derechos y su relación con el cine en Colombia.

Palabras clave: derechos de autor, obras cinematográficas, cine, derechos conexos, ley de cine.

\section{Abstract:}

This research work aims to delve into the background issues that led to the protection acts of the film productions in Colombia. In addition, this paper reflects on how the legislative evolution concerning film issues occurred hand in hand with the industry growth in our country. The scope of the copyrights for every film author and interpreter in our country is also explored herein. Finally, this work studies the evolution of their copyrights and how it relates to the film industry in Colombia.

Keywords: copyright, film production, cinema, related rights, film Act.

\section{SUMARIO}

INTRODUCCIÓN. I. LA PRODUCCIÓN DE CINE EN COLOMBIA. II. MARCO GENERAL DE PROTECCIÓN DE LAS OBRAS PROTEGIDAS POR EL DERECHO DE AUTOR. 1886-1942. III. LA LEY 9 DE 1942: EL PRIMER INTENTO. IV. LEY 86 DE 1946. V. CREACIÓN DEL FOCINE. VI. LA LEY 23 DE 1982 Y LA PROTECCIÓN DE LOS DERECHOS DE LOS CREADORES EN UNA OBRA CINEMATOGRÁFICA. VII. LA LEY DE CINE Y LA LEY FANNY MIKEY. UN IMPULSO

Notas de autor 


\begin{abstract}
AL DESARROLLO DEL CINE EN COLOMBIA. VIII. ¿QUÉ PASÓ CON LOS DIRECTORES Y DEMÁS AUTORES DE LA OBRA CINEMATOGRÁFICA? LEY PEPE SÁNCHEZ DE 2017. CONCLUSIONES. BIBLIOGRAFÍA.
\end{abstract}

\title{
INTRODUCCIÓN
}

El 28 de febrero de 2016 compitió por el premio a la "mejor película extranjera" la primera película colombiana nominada a los premios Óscar: El abrazo de la serpiente de Ciro Guerra. ${ }^{1}$ Por su parte, la 68 edición del Festival de Cannes -realizada entre el 13 y el 24 de mayo de 2015- entregó al caleño César Acevedo la Cámara de Oro por su película La tierra y la sombra, el premio más importante recibido por la industria cinematográfica colombiana. ${ }^{2}$ Además, Colombia, magia salvaje, un documental sobre la diversidad biológica de nuestro país, logró coronarse en 2015 como la película más vista de la historia del cine colombiano. ${ }^{3}$ Todo esto, se enmarca en que el pasado fue el año más exitoso en la industria cinematográfica colombiana: aumentó en un $22 \%$ el estreno de películas nacionales y en 7,9\% su participación en el mercado. ${ }^{4}$

Seguramente, dentro de los factores que propiciaron este fenómeno, uno de los más importantes es la expedición de una serie de normas que incentivan hoy la producción de cine nacional. Así, entre otras, tenemos la Ley 814 de 2003 -Ley de cine- y la Ley 1556 de 2012. La primera, que estableció una contribución parafiscal en cabeza de los exhibidores cinematográficos, creó el Fondo para el Desarrollo Cinematográfico dirigido a conceder estímulos a la producción y recuperación del cine nacional. La segunda, por su parte, creo el Fondo Fílmico Colombia, que paga contraprestaciones a las empresas productoras de obras cinematográficas extranjeras, cuando estas realicen cuantiosas inversiones en el desarrollo del cine en Colombia.

Nos encontramos, entonces, ante el resultado de un desarrollo legislativo que reivindicó a la producción de cine como un sector productivo valioso para el enriquecimiento económico y cultural colombiano. Esto es de importancia mayúscula en un país como el nuestro, en el que la historia de la producción de cine está plagada de fracasos generados por la ausencia de apoyo estatal.

No obstante -cabe preguntarse-: ¿Es esto suficiente teniendo en cuenta que el apoyo a directores, guionistas y escritores de cine, no ha avanzado al mismo ritmo? Si partimos de que el artículo 89 de la Ley 23 de 1983 presume que los derechos patrimoniales pertenecen exclusivamente al productor de la obra -salvo pacto en contrario- y advertimos que los ingresos económicos, derivados de las producciones cinematográficas nacionales han aumentado progresivamente, consideramos justo que los autores también participen de los frutos de sus creaciones.

Este trabajo es, por tanto, el resultado de una investigación en torno a las dificultades históricas que ha padecido el desarrollo del cine en Colombia, causadas por la indiferencia de cada uno de los gobiernos a invertir en este rubro y la llegada tardía de herramientas jurídicas. Igualmente, es una invitación a que el apoyo legislativo y presupuestal continúe con los directores, guionistas, actores, escritores de cine y todos aquellos que tienen un trabajo creativo en la obra audiovisual, de la misma manera en que, desde hace algunos años, se apoya a los productores. Todo, a propósito de la promulgación de la reciente Ley Pepe Sánchez, que pretende que los autores de producciones audiovisuales puedan percibir ganancias por cada vez que sus trabajos se divulguen públicamente. Es necesario que se reconozca -tal como ocurrió con la Ley 1403 de 2010 respecto a intérpretes audiovisuales- un derecho inalienable de los autores a recibir una regalía proporcional por el trabajo realizado en la obra, cada vez que esta se exhiba públicamente o se alquile comercialmente.

En un primer momento revisaremos cómo se desarrolló la producción de cine colombiano a lo largo del siglo XX y la relación que ha tenido con las normas proferidas al respecto. Posteriormente, analizaremos los cambios ocurridos en el desarrollo de producciones audiovisuales a partir de la Ley 814 de 2013 y cómo ello ha influido en los logros que hoy disfruta nuestro cine. Enseguida, realizaremos un recuento de 
las normas referentes contenidas en la Ley 23 de 1982 -que hoy fundamentan los derechos en cabeza de los autores de producciones audiovisuales sobre sus obras- y, finalmente, examinaremos cuáles fueron los cambios realizados por la Ley Pepe Sánchez y el impacto que podría tener en la industria cinematográfica nacional.

\section{LA PRODUCCIÓN DE CINE EN COLOMBIA}

\section{De la escasa producción en el inexistente apoyo estatal: 1922-1942}

Si bien las primeras proyecciones de cine en Colombia se dieron en $1897,{ }^{5}$ en el puerto de Colón de Panamá (en aquel momento parte de la Gran Colombia), puede decirse que fueron los hermanos Di Doménico los pioneros de la exhibición y producción de cine en Colombia. ${ }^{6}$ Francesco y Vicenzo Di Doménico, ${ }^{7}$ dos italianos que decidieron radicarse en Bogotá en 1909, en 1912 inauguraron el mítico Salón Olympia, que proyectó la película Diario de un joven pobre. ${ }^{8}$ Aquel salón, ubicado en el costado sur de la calle 25 (entre las carreras séptima y trece) y que medía, por lo menos, setenta metros de largo por treinta metros de ancho (con capacidad para cerca de cinco mil personas) se convirtió, casi inmediatamente, en el sitio predilecto de entretenimiento sano de la población bogotana. ${ }^{9}$ En dos localidades se reunían ciudadanos de todas las clases, para ver las proyecciones de películas europeas y estadounidenses ambientadas, unas veces, al ritmo de Verdi, Wagner y Rossini y otras -en el caso de comedias "más movidas" - con bambucos y pasillos. ${ }^{10}$

Motivados por el éxito del negocio de la exhibición, los hermanos Di Doménico fundaron en 1914 la Sociedad Industrial Cinematográfica Latinoamericana (SICLA) con la que produjeron obras audiovisuales como La fiesta del Corpus (1915) ${ }^{11}$, El drama del 15 de octubre (1915) ${ }^{12}$, Aura o los violetas (1924) y El amor, el deber y el crimen (1926). Tales películas, entre otras, lograron rentabilizar la empresa hasta hacerla atractiva al grupo antioqueño Cine Colombia, que compró a SICLA en 1927. ${ }^{13}$ No obstante, a pesar del éxito conseguido, la falta de apoyo estatal siempre fue el gran obstáculo para la realización y desarrollo del cine. Así lo expresó Donato Di Doménico en una entrevista concedida en 1964:

Al respecto tengo una experiencia personal que muestra la falta de estímulo del Gobierno a iniciativas cinematográficas. Mi primo Vicente di Doménico, al vender la empresa a Cine Colombia, se radicó en Barcelona, España, donde montó un laboratorio cinematográfico muy completo. Durante la guerra civil española, y como era natural, se suspendieron los negocios de cine. Al terminar la guerra me escribió Vicente que deseaba establecerse de nuevo en Colombia trayendo todo su laboratorio para uso en desarrollo del cine colombiano. Hice toda clase de diligencias ante toda clase de entidades oficiales y particulares para ver si era posible establecer el laboratorio de Vicente en Bogotá, pero todas mis diligencias fueron inútiles ante la indiferencia que por el proyecto demostraron tanto el Gobierno como los particulares. ${ }^{14}$

Sin embargo, cabe resaltar que algunos estudiosos del cine colombiano, piensan que además de los hermanos Doménico, ya desde 1914 la revista El Kine, ${ }^{15}$ publicada en Sincelejo, se hacía referencia a la empresa Kinematógrafos, que funcionaba en Sincelejo desde 1909, después de la llegada de sus fundadores, alrededor del año 1904, como se extracta de la siguiente cita:

El Kine no será exclusivamente órgano de nuestra empresa comercial. No. No solo de pan vive el hombre. Al par que haga propaganda de ella, velará por los intereses de toda la comarca, y de un modo especial, por la de Sincelejo, pedazo de tierra colombiano donde, hace más de un lustro, plantamos nuestra tienda de hermanos. ${ }^{16}$

Por otra parte, otros pioneros de la producción de cine en Colombia fueron los hermanos Acevedo. Arturo Acevedo Vallarino, integrante del grupo de tertulia "Gruta simbólica" (conjuntamente con el poeta Julio Flórez y el posteriormente presidente Enrique Olaya Herrera) realizó con sus hijos, Álvaro y Gonzalo entre 1920 y 1950 - la más fecunda producción de cine documental que se haya visto en todo el siglo XX. ${ }^{17}$ 
Gracias a ellos fue posible El noticiero nacional, de Acevedo Sono Films, que con 250 entregas registró los acontecimientos más importantes del segundo cuarto del siglo XX, entre ellos los más renombrados discursos. 18 Además, los hermanos Acevedo fueron los primeros colombianos en producir cine parlante, cuando en 1937, en conjunto con el ingeniero alemán Carlos Schroeder, produjeron la película La apoteosis de Enrique Olaya Herrera, documentando los homenajes póstumos realizados al expresidente colombiano. ${ }^{19}$

Simultáneamente, los hermanos Gabriel Ángel y Guillermo Vélez crearon Cine Colombia y compraron la compañía y los laboratorios de la familia Di Doménico (los únicos en el país para el procesamiento de negativos), supuso el encarecimiento de la producción de cine y el abandono de aquellos, del desarrollo de largometrajes, para entregarse a la compra y construcción de teatros para la exhibición de cine extranjero. ${ }^{20}$ Puede resaltarse entonces, de esta etapa, que solo el emprendimiento individual de los productores permitió el nacimiento de la industria cinematográfica nacional. Es que nunca existió apoyo estatal al desarrollo de esta industria, al contrario, para los productores y realizadores nacionales solo existió indiferencia de parte de nuestros dirigentes. Así lo expreso, en su momento, Gonzalo Acevedo al decir:

El estancamiento del cine colombiano se debe a la absoluta falta de apoyo oficial, pues ningún gobierno ha visto en esta industria el gran valor que puede tener, tanto como productor de divisas al exportarlo, como por su inmenso valor educativo sobre las miles de personas que emplearía la industria del cine”. [...] Creo, que [la falta de capital oficial se debe] a la misma inseguridad legal del cine en Colombia, pues, como usted sabe, no hay leyes que lo reglamenten ni protejan. [...] Si, por ejemplo, el doctor Alfonso López Michelsen hubiera invertido en Colombia el capital que ha gastado en los estudios de México en la producción de algunas películas, ese capital hubiera servido de base para la industria del cine en Colombia. ${ }^{21}$

\section{MARCO GENERAL DE PROTECCIÓN DE LAS OBRAS PROTEGIDAS POR EL DERECHO DE AUTOR. 1886-1942}

A pesar de la referencia a la protección de las obras del intelecto desde la misma época de la independencia en Colombia, cuando el Gobierno de Francisco Paula Santander ${ }^{22}$ expidió la primera ley de derecho de autor en $1834,{ }^{23}$ seguido por lo estipulado artículo 43 de la Constitución de 1858, el artículo 709 del código civil de Cundinamarca de 1859, uno de los antecedentes importantes que se dieron en nuestro país en el marco de las obras protegidas por el derecho de autor en relación con las obras cinematográficas, fue el artículo 35 de la Constitución Política de $1886^{24}$ el que estableció lo siguiente: "Será protegida la propiedad literaria y artística, como propiedad transferible, por el tiempo de la vida del autor y ochenta años más, mediante las formalidades que prescriba la ley".

La Ley 32 de 1886, reglamentada por los decretos 665 de 1886 y 1226 de 1823, en su artículo 6 determinó que la obra literaria o artística es el producto de un esfuerzo o trabajo personal de la inteligencia, animación o arte. ${ }^{25}$ Cuando la norma se refiere a la propiedad literaria y artística, debe entenderse por ello a todas las producciones comprendidas en dichos campos, cualquiera que sea el modo de expresión, como los libros, folletos, alocuciones, obras dramático y dramático-musical, composiciones musicales con música o sin ella y por supuesto las obras cinematográficas, ${ }^{26}$ entre otras.

Este reconocimiento legal, que se extendió a las nacientes obras cinematográficas, que como lo anotamos anteriormente llegaban a Colombia desde el año 1897 y que ya en 1928, planteaba un gran hito en la historia de nuestro cine, y por ende de los derechos de autor y la distribución de las obras, con la compra de la empresa Cine Colombia a los estudios de los hermanos Di Dómenico. ${ }^{27}$

Cabe destacar que Colombia, a pesar de no ser parte del Convenio de Berna, que curiosamente fue liderado por el colombiano José María Torres Caicedo, ${ }^{28}$ uno de los fundadores de la Asociación Literaria Internacional (ALI) en 1880, luego, desde 1884, Fundación Literaria y Artística Internacional (ALAI), ${ }^{29}$ la protección de las obras literarias y artísticas, tuvo en nuestra Constitución Política de 1886 una protección 
mayor de la estipulada en el Convenio de Berna, ya que este en su artículo 7 establece la protección concedida a las obras artísticas o literarias, se extienden a la vida del autor más cincuenta años y en el caso particular de las obras cinematográficas cincuenta años después de que la obra haya sido dada a conocer al público con el consentimiento del autor o desde la realización de la obra desde el momento en que se haya creado, en caso de no haberse publicado. ${ }^{30}$ Así, Colombia que no tenía una protección especial para obras cinematográficas, según la Constitución de 1886, tenía una protección para ellas de la vida del autor más ochenta años.

Esta protección de la propiedad intelectual por parte de nuestro ordenamiento jurídico fue refrendada por el Código Civil de 1887, aún vigente, que en el artículo 671 establece que las producciones del ingenio y del talento son una propiedad de sus autores. ${ }^{31}$

A pesar de dicha protección es importante resaltar que el Código Penal colombiano de 1890 dejó sin efectos varias disposiciones de la Ley 32 de 1886 y la infracción a los derechos de autor, durante varios años no contó con penas que castigaran los delitos de propiedad intelectual. ${ }^{32}$

\section{LA LEY 9 DE 1942: EL PRIMER INTENTO}

Desde 1938, Ducrane Films -creada por los hermanos Duperly y los Crane Uribe- empezó a desarrollar iniciativas de cine sonoro, "en medio de las dificultades técnicas, el escaso capital, la inexperiencia en el cine de actores y personal artístico [y] la inestabilidad de la corriente eléctrica que en Bogotá, por aquellas épocas, ocasionaba continuos cambios en el voltaje”, ${ }^{33}$ se generó el ambiente propicio para la expedición de la Ley 9 de 1942, que en el Gobierno de López Pumarejo fue el primer intento de fomentar la producción fílmica colombiana.

Se intentó fomentar la producción de cine por parte de compañías productoras nacionales, de dos maneras: la primera fue facultar al Gobierno para eximir del pago de los derechos de aduana "para las sustancias químicas necesarias para la elaboración de cintas y para el material virgen (película) que introduzcan al país con destino a la producción a que se dediquen". ${ }^{34}$ La segunda fue autorizar al Gobierno para "eximir, en todo o en parte, a los teatros o empresas que exhiban este material, del pago de los impuestos nacionales que gravan los espectáculos públicos". ${ }^{35}$ Sin embargo, nuevamente el poco interés del Gobierno nacional por fomentar la producción y el desarrollo de la industria cinematográfica, se hizo evidente en el hecho de que la Ley 9 de 1942 solo fue reglamentada 25 años después, en 1977 , por medio del decreto reglamentario $2288 .{ }^{36}$

A pesar de todo, en algo avanzó la producción de cine. No obstante el atraso de la industria colombiana con respecto a la mexicana, la brasilera o la argentina, se dieron avances significativos: la primera película argumental sonora Las flores del Valle de Máximo Calvo ${ }^{37}$ se estrenó en 1941 y, entre 1943 y 1945 , se produjeron nueve películas "en pobres condiciones técnicas" dirigidas a imitar las comedias musicales de los mexicanos" ${ }^{38}$ La "ausencia de una legislación y una política de Estado en apoyo del cine propio son algunos de los factores que [propiciaron] el declive de la producción de cine nacional de largometrajes, desplazándose a noticieros y a cortos documentales y publicitarios". ${ }^{39}$ Ello tuvo como consecuencia que solo hasta la década de 1940 pudo consolidarse el cine parlante en la producción audiovisual colombiana. Esta década, compleja por la carencia de organización de las productoras y la falta de rentabilidad del negocio, vio morir a la Ducrane Films en 1947, que anunciando en 1943 la producción de tres películas y la construcción de un complejo cinematográfico en Sasaima, solamente logró estrenar una y vio perecer sus registros en un incendio. ${ }^{40}$

En 1950, solo después de que el país pudo recuperarse en parte de los acontecimientos del 9 de abril de 1948, ocurrió una renovación forzada de la industria nacional. El hecho de que en el Gobierno de Gustavo Rojas Pinilla se fomentase un desarrollo cultural, principalmente de la producción de televisión, permitió la entrada de manifestaciones culturales -como revistas especializadas- que condujeron a la creación de cineclubes que generaron una expansión en la exhibición de cine de calidad. ${ }^{41}$ La llegada de las películas de acetato y la 
entrada al país de cámaras más livianas fue el germen para el nacimiento de una generación de cineastas que vieron en la producción audiovisual un instrumento de propaganda y una opción social y política. Así nació la llamada Generación de los maestros: un grupo de jóvenes, de edad, estudios en el exterior y una idea específica de cine común, que hicieron que el séptimo arte se convirtiera en un reflejo de la realidad colombiana. ${ }^{42}$ Empero, la falta de fondos privó a las productoras colombianas de hacer cine de calidad, dejando a las salas de exhibición solamente películas de Hollywood e "historias de hacendados y charros mexicanos" ${ }^{43}$

\title{
IV. LEY 86 DE 1946
}

Aunado a la expedición de la Ley 9 de 1942, y dado el creciente interés que suscitaba en el contexto colombiano todo lo referente a la producción de las artes y las letras, se expide una nueva ley de derechos de autor, encomendada en su presentación al Representante Guillermo Chávez Chávez, ${ }^{44}$ quien de una manera muy prolija, diría ante la Comisión Primera del Senado las siguientes palabras que, sin duda, enmarcan el espíritu de la producción de esa ley, que buscaba darle una mayor importancia a la protección de obras literarias y artísticas y, por tanto, a las obras cinematográficas:

\begin{abstract}
A corregir este abandono paradójico e injustificado se encamina el proyecto de ley del honorable representante Silvio Villegas y es claro que su oportunidad y conveniencia están fuera de discusión. Un país de escritores y de artistas no puede vivir sin leyes que garanticen y protejan eficazmente las obras del espíritu. He aquí por qué el suscrito, deseando servir con lealtad los intereses de la República y corresponder al mismo tiempo con dignidad a la confianza que en él depositó el hombre sabio y virtuoso que preside la comisión primera constitucional de la Cámara (Alberto Lleras Camargo), al darle la ponencia del proyecto del honorable representante Villegas, se ha tomado un trabajo mucho mayor del obligado y ha elaborado un proyecto global, el mismo que presenta a vuestra consideración como pliego de modificaciones, previas las indicaciones y explicaciones que hace en el capítulo siguiente. ${ }^{45}$
\end{abstract}

Esta ley enfatizó en la importancia de las obras literarias y artísticas ${ }^{46}$ fijando una serie de sanciones contra quienes escribieran, grabaran, difundieran, cedieran, ejecutaran, representaran vendieran como suya, $o$ publicaran o difundieran como una obra de dominio público, una obra que perteneciera al dominio privado y al que infringiera las normas de propiedad intelectual de la ley. ${ }^{47}$ Igualmente, esta ley creó el valiosísimo Registro Nacional de Propiedad Intelectual, ${ }^{48}$ que después se convertiría en el Registro Nacional de Derecho de Autor.

Esta ley fue de las primeras en utilizar el término "derecho de autor". Igualmente, estableció la obligatoriedad de remunerar al autor por su producción literaria o artística, así como por su representación o ejecución pública de las obras. En consecuencia, se establecieron dos tipos de derechos. Unos principales:

[...] referidos a los actos directos de disposición de la obra literaria o artística para celebrar contratos de venta, edición, adaptación, grabación, etc., y los universalmente reconocidos como pequeños derechos que son los que dicen relación con la ejecución pública de la obra. ${ }^{49}$

Nuevamente, esta ley en su artículo segundo hace referencia a la protección de obras literarias o artísticas, incluyendo las obras cinematográficas en el ámbito de protección. De la misma forma, esta ley consideró al autor como titular de la obra, y en virtud de esa condición, los facultó para autorizar la adaptación y presentación pública de sus obras por la cinematografía, considerándola como una obra original. ${ }^{50}$

Esta ley hace una importante mención a los derechos surgidos de las obras cinematográficas, ya que estableció que el productor de la película, salvo pacto en contrario tenía derechos iguales con el autor del argumento y el compositor de la música si la hubiere. Sin embargo, el productor podía proyectarla sin el consentimiento del autor del argumento o del compositor, sin perjuicio de los derechos que surgieran por la colaboración. Sin embargo, tanto el autor del argumento como el compositor de la música, podían publicar 
separadamente como una obra literaria o artística de otra especie y publicar y ejecutar por separado la música, respectivamente. ${ }^{51}$

Esta mención es una alusión clara a los derechos tanto del productor de la obra cinematográfica, que para este caso era considerado como su autor y, por tanto, titular de sus derechos, y los derechos que surgen del guionista o creador del argumento y del compositor musical, como colaboradores de la obra cinematográfica y como titulares del argumento y de la composición musical. Sin embargo, esta ley no hizo distinción entre los derechos del director y el productor de la obra cinematográfica.

De todas maneras, el artículo 32 de la mencionada ley estableció a favor del productor que:

Al exhibirla en público, debe mencionar su propio nombre, el del autor del argumento o el del autor de la obra original de la cual se haya tomado el argumento de la obra cinematográfica, el del compositor, el del director artístico o adaptador y el de los intérpretes principales.

Con ello, y a pesar de que Colombia para 1946 no hacía parte del Convenio de Berna, ${ }^{52}$ y en consecuencia, no vemos en esta ley una distinción expresa entre derechos patrimoniales y morales, que posteriormente se introducirán en la Ley 23 de 1982, sí denotamos cómo el productor debía mencionar los créditos suyos y del autor del argumento o el del autor de la obra original de la cual se hubiera tomado el argumento de la obra cinematográfica, el del compositor, el del director artístico o adaptador y el de los intérpretes principales. ${ }^{53}$ Esto correspondía a una mención muy introductoria de un derecho de paternidad a favor de estos creativos.

El intérprete de una obra teatral, musical o literaria tenía derecho a exigir una remuneración por:

Su interpretación a quien la retransmita por medio de la radiotelefonía o de la televisión o la imprima sobre disco, película, cinta o cualquier elemento apto para la reproducción sonora o visual. Si no hubo acuerdo previo o no se puede llegar a un arreglo ulterior, la remuneración será fijada por el juez, previo juicio sumario. ${ }^{54}$

Igualmente, podía "oponerse a la divulgación de su interpretación, siempre que de la reproducción de la misma se siga un grave e injusto perjuicio para sus intereses artísticos”.

Esta normatividad era una mención a los llamados derechos conexos o derechos vecinos, que gozarían los artistas, intérpretes o ejecutantes de este tipo de obras, a tener una remuneración por su ejecución de parte de quien la trasmitiera y a impedir su divulgación en caso de afectar sus intereses artísticos. Sin embargo, esta ley no mencionó ningún tipo de derecho a favor de los interpretes por la posterior explotación de la obra cinematográfica y los derechos de comunicación pública de la misma, más allá de la remuneración inicial por sus servicios artísticos.

\section{CREACIÓN DEL FOCINE}

Solo hasta 1971, con el Decreto 979, el Estado colombiano dio apoyo directo a los productores nacionales de cine. Tal decreto estableció una cuota obligatoria de producciones nacionales para los exhibidores, una exención del $25 \%$ del impuesto a los espectáculos públicos por la exhibición de cine y se autorizó a la Superintendencia de Industria y Comercio para que creara un fondo para el otorgamiento de préstamos a largo plazo y estableciera un "sobreprecio" para cada boleta vendida al espectador. ${ }^{55}$ Tal "sobreprecio", casi del $15 \%$ de las entradas, era repartido entre el productor de la película y la compañía distribuidora. ${ }^{56}$

Posteriormente, mediante el Decreto 2288 de 1977, se creó uno de los mecanismos esenciales para el desarrollo del cine del último cuarto del siglo pasado: el Fondo de Fomento Cinematográfico (Focine). Aquel fondo se destinó a la financiación de la industria cinematográfica colombiana a partir del otorgamiento de créditos garantizados con los negativos de las películas. Paralelamente, el Decreto 319 de 1983 facultó al Focine para producir largometrajes, a tal punto que, durante los diez años siguientes, solo una película de larga duración se hizo sin la participación del fondo. ${ }^{57}$ 
Con todo lo anterior, el sistema del Focine fue liquidado en 1992. Ello en razón a que, desde un principio, las salas de exhibición entorpecieron el pago del gravamen y lo sometieron a controversias legales; los desarrollos legislativos para solucionar el problema simplemente no funcionaron; se liberaron los precios de la boletería de cine con el Decreto 183 de 1988 y la prohibición de las rentas de destinación específica a partir de la Constitución de 1991, artículo 359. ${ }^{58}$ Así, desprovisto del gravamen que alimentaba el Fondo y sin recuperar lo invertido en las películas realizadas, el Decreto 2125 de 1992 acabó con la primera política pública seria para el desarrollo de largometrajes y cortometrajes nacionales.

Debe recordarse, que fue en el periodo entre 1977 y 1992, que se desarrollaron los avances más grandes del siglo en la producción de cine colombiano. En esta época se desarrolló el Grupo de Cali, que en contraposición al llamado "benjumeismo", produjo largometrajes que reivindicaron una forma diferente de hacer cine. Dentro de la vigencia del Focine, encontramos míticas producciones como Pura sangre de Luis Ospina (1982), Carne de tu carne de Carlos Mayolo (1983) y Cóndores no entierran todos los dias de Francisco Norden (1983).

\section{LA LEY 23 DE 1982 Y LA PROTECCIÓN DE LOS DERECHOS DE LOS CREADORES EN UNA OBRA CINEMATOGRÁFICA}

Si bien, como lo reseñamos anteriormente, la Ley 86 de 1946 ya hacía alusión a la protección de las obras cinematográficas y a varios de sus creadores, esta era insuficiente dados los aportes creativos de un gran número de personas para la consecución de la protección, que en consecuencia merecían una amparo jurídico a sus derechos fruto del trabajo intelectual. Sin embargo, como veremos adelante no todas las personas que realizan un trabajo creativo en la obra cinematográfica ${ }^{59}$ tienen una protección jurídica del derecho de autor, como los maquilladores, directores de cámara, sonidistas, etc. ${ }^{60}$

Sobre este aspecto el doctrinante Felipe Rubio considera que:

Normalmente las obras audiovisuales son realizadas por una conjunción de aportes tales como los argumentos, libretos, diálogos, la dirección, la musicalización entre otras, que hacen pensar en la necesidad de determinar quiénes son los autores de la obra audiovisual. La distinción es muy importante pues en esta clase de obras, además de los autores, también participa otro grupo de personajes como los actores o los intérpretes de las obras musicales que se encuentra protegido por los derechos conexos. También participan otros personajes como los sonidistas, camarógrafos asistentes, utileros entre otros, que no disponen de protección alguna por parte del derecho de autor o los derechos conexos.

Así las cosas, la ley de derecho de autor considera a la obra audiovisual como si fuera una obra original (única y creada como de primera mano), sin perjuicio, por supuesto, de las obras incluidas o adaptadas en ella. ${ }^{61}$

En consecuencia, esta ley en su artículo 95 establece que los autores de la obra cinematográfica son: 1) el director o realizador; 2) el autor del guion o libreto cinematográfico; 3 ) el autor de la música y el dibujante o dibujantes, en caso de tratarse de diseños animados. ${ }^{62}$

Igualmente, esta ley hace referencia al disfrute de unos derechos morales y patrimoniales, ya que esta incorpora el llamado sistema dualista de derecho de autor, que hace una distinción entre los derechos de explotación económica de las obras y los derechos que protegen la personalidad del autor en relación con su obra, también llamados derechos patrimoniales y derechos morales, ${ }^{63}$ respectivamente.

Los derechos morales son reconocidos en la Ley 23 de 1982 al director, ${ }^{64}$ en su calidad de autor de la obra. Dentro de los derechos morales reconocidos en el artículo 30 de la Ley 23 de 1982 y luego ratificados en el artículo 11 de la Decisión Andina 351 de 1993, tenemos el de paternidad referido al derecho que tiene el autor a que su nombre sea reivindicado siempre como el escritor de la obra. Por ejemplo, la película colombiana Soñar no cuesta nada de 2006, que contó con un total de 1198172 espectadores, ${ }^{65}$ debe siempre reivindicar su autoría al director Rodrigo Triana. El derecho de integridad referido a la facultad que tiene el 
autor de oponerse a toda deformación o mutilación de la obra que atente contra su honor o reputación. ${ }^{66}$ Un ejemplo de ello lo reseña la doctrinante Natalia Tobón en el caso de Monty Python’s Flying Circus, en el que la British Broadcasting Company (BBC), de Londres licenció la exhibición de su película a una compañía estadounidense que para adaptarlo a la idiosincrasia de su país, corto algunos fragmentos, que para el juez que conoció el caso, correspondía a una infracción al derecho de copyright de los ingleses ${ }^{67}$ por la mutilación de la obra, ya que en Estados Unidos la ley no reconoce los derechos morales de autor. ${ }^{68}$ De la misma forma, el autor tiene derecho a ejercer la ineditud de la obra, es decir, a no publicarla. En menor medida en las obras cinematográficas el autor puede ejercer el derecho a modificar la obra después de publicada o a retractarse de ella y sacarla del mercado. En todo caso, son derechos de difícil aplicación, ya que el autor en caso de ejercerlos debe indemnizar a todos aquellos a los que haya ocasionado un perjuicio. ${ }^{69}$

Sin embargo, y a pesar de que el director de la película es considerado como su autor, el artículo 98 de esta ley establece que el productor es el titular de los derechos patrimoniales sobre la obra, a menos que se pacte en contrario. ${ }^{70}$ Esto, claramente, pone en una situación muy desventajosa, especialmente, a los directores de largometrajes y cortometrajes, ya que el verse beneficiados por los rendimientos económicos de sus obras se ven supeditados a la aquiescencia de quien financia la producción y, como en cualquier negocio, quien pone el capital impone las condiciones. Este aspecto precisamente se abordará en la Ley Pepe Sánchez, que analizaremos más adelante.

Los derechos patrimoniales están consignados en el artículo 12 de la Ley 23 de 1982, refrendados en el artículo 13 de la Decisión Andina 351 de 1993. El ejercicio de estos derechos concede a su titular, es decir, al productor de las obras cinematográficas en este caso, la potestad de autorizar o prohibir la reproducción de la obra, es decir, su fijación en un soporte material o digital, la posibilidad de hacer copias de ella, la comunicación de la obra a un amplio grupo de personas, en lo que comprende la proyección o exhibición pública de las obras cinematográficas, ${ }^{71}$ la distribución, vendiendo, arrendando o alquilando la obra y su transformación o adaptación a otros formatos. ${ }^{72}$ Cabe resaltar que en materia de derechos de autor, en las obras cinematográficas, no aplica la figura del agotamiento del derecho. ${ }^{73}$ Igualmente, es importante señalar que estos derechos son aplicables al entorno digital, ${ }^{74}$ como lo veremos en el siguiente párrafo.

Con la adopción de los llamados Tratados de Internet ${ }^{75}$ de la OMPI, el Tratado de la OMPI de Derecho de Autor (TODA), el Tratado sobre Interpretaciones y ejecuciones de fonogramas (TOIEF), en Colombia se introdujeron normas que modernizaron el derecho de autor con el advenimiento de las nuevas tecnologías de la información, especialmente Internet. Canto a los derechos patrimoniales de autor se implantó el derecho de puesta a disposición en los entornos digitales, ${ }^{76}$ que corresponde a una forma de comunicación pública de las obras en el que el usuario pueda acceder a ellas desde el momento y lugar que ellos elijan. ${ }^{77}$ Colombia ratificó estos tratados por medio de las leyes 545 de 1999 y 565 de $2000{ }^{78}$

En lo que tiene que ver con los guionistas respecto de su guion, los compositores de la música y de la letra respecto de su obra musical y los dibujantes de diseños animados, en su calidad de autores de sus obras son titulares de derechos a la explotación de sus trabajos, salvo que los hayan cedido en favor del productor de la película. ${ }^{79}$ Por ejemplo, el músico John Williams que hizo la música original de la película Star Wars, ${ }^{80}$ cedió sus derechos al productor, para su comercialización y explotación, mientras que, en el caso del grupo Niche, en la película Ciudad delirio de 2014, ${ }^{81}$ en la que se utilizó la canción Cali pachanguero, ${ }^{82}$ los derechos siguen perteneciendo al titular de la canción y no al productor de la película, ya que la figura jurídica utilizada en este caso fue un contrato de licencia de uso.

Sin embargo, y como lo anotamos anteriormente, los derechos patrimoniales sobre la obra cinematográfica corresponden al productor, a menos que se pacte en contrario, con lo cual esta presunción de titularidad legal, a favor del productor, ${ }^{83}$ excluye a los participantes del proceso creativo de la concepción de este tipo de obras de poderse beneficiar de su explotación en todo el mundo, especialmente los directores, ya que ellos a pesar 
de ser los autores, no tenían los derechos patrimoniales sobre ella y no podían recibir estos beneficios, así fueran reconocidos por otros países en virtud del principio de reciprocidad y trato nacional del Convenio de Berna, ${ }^{84}$ según el cual los países miembros no están obligados a reconocer los derechos de los nacionales de otros países que no sean reconocidos a sus nacionales. Esto por años ha impedido que los directores de las obras cinematográficas sean remunerados por la explotación de derechos de comunicación pública en otras latitudes, en los que ese derecho es reconocido.

En lo que respecta a los derechos conexos, la Ley 23 de 1982 otorga a los artistas, intérpretes y ejecutantes de las obras protegidas por el derecho de autor el derecho de autorizar o prohibir las interpretaciones no fijadas, o en vivo, respecto de la comunicación pública, reproducción, a menos que la comunicación pública constituya por sí misma una ejecución radiodifundida o se haga a partir de una fijación previamente autorizada. ${ }^{85}$ Sin embargo, esta normatividad solo concedió los derechos de remuneración por comunicación pública a los artistas de obras musicales, ${ }^{86}$ dejando por fuera a los artistas y actores de obras cinematográficas que durante años se privaron también de percibir estos beneficios, en especial del extranjero.

\section{LA LEY DE CINE Y LA LEY FANNY MIKEY. UN IMPULSO AL DESARROLLO DEL CINE EN COLOMBIA}

Sin olvidar la década de los noventa y las importantes producciones en su momento, el siguiente desarrollo legal en torno al apoyo de productores y empresas distribuidoras, se dio en 2003 con la Ley 814. Esta permitió un incremento en la producción nacional al crear el Fondo para el Desarrollo Cinematográfico (FDC) financiado por una contribución realizada por los exhibidores y distribuidores, que consiste en una cuota de entre el $5 \%$ y $8,5 \%$ del precio de la boletería de todas las películas que proyecten. ${ }^{87}$ Así, por lo menos el $70 \%$ de los ingresos del FDC se destinan a la realización de largometrajes y cortometrajes colombianos. ${ }^{88}$ Igualmente, se establecieron reducciones en el pago de la Cuota para el Desarrollo Cinematográfico, por la exhibición y distribución de películas de producción nacional ${ }^{89}$ y se definieron beneficios tributarios que incentivan la donación o inversión en producción cinematográfica. ${ }^{90}$

Todo esto generó un ambiente propicio para que los productores se animasen a desarrollar cine con apoyo de los préstamos estatales y para que los distribuidores y exhibidores presentasen películas colombianas. Así, fue como se hicieron posibles películas como María, llena eres de gracia de Jaime Osorio (2004), cuya protagonista fue nominada a un premio Óscar y ganó el Oso de Plata a la mejor interpretación femenina en el Festival de Cine de Berlín; La Sombra del Caminante de Ciro Guerra (2004), ganadora de un premio en el festival de cine de San Sebastián; Satanás de Andi Baiz (2007), ganadora del premio a mejor película del Festival International Des Espoirs Du Cinéma, en Mónaco; Hongos de Óscar Navia (2014), ganadora del Premio Especial del Jurado del Festival de Locarno; El abrazo de la serpiente de Ciro Guerra (2015), primera película colombiana nominada a los premios Óscar y, entre muchas otras, La tierra y la sombra de César Acevedo (2015), ganadora de la Cámara de Oro del Festival de Cannes, el premio internacional más importante ganado alguna vez por una película colombiana. Tenemos, entonces, que en tres lustros la industria cinematográfica ha logrado, con el apoyo de una iniciativa pública seria, lo que no había logrado en casi cien años de historia.

Además, es fundamental la Ley 1556 de 2012, que construyó mecanismos que promueven la inversión extranjera en servicios cinematográficos colombianos y generó ingresos al país por más de ochenta y seis mil millones de pesos. ${ }^{91}$ Concretamente, lo que estableció esta ley fue la creación del Fondo Fílmico Colombia, que entrega contraprestaciones monetarias a las compañías productoras de cine extranjeras que realicen producciones en nuestro país, cuando inviertan, por lo menos, 1.800 SMLMV. ${ }^{92}$ Gracias a esto, para el 23 
de noviembre de 2016, ya iban veinticinco proyectos aprobados que se han beneficiado de lo estipulado en la Ley $1556 .{ }^{93}$

Por lo anterior observamos, que solo gracias a la inversión estatal en proyectos de promoción en el desarrollo del cine, se ha logrado consolidar una escena de realizadores de largometrajes y cortometrajes de calidad en el que se puedan desarrollar contratos que ayuden a la promoción de la industria cinematográfica. ${ }^{94}$ Visto esto, pasamos a revisar cómo es la situación de los directores con respecto al avance actual de la industria.

En cuanto a los derechos de los artistas, intérpretes y ejecutantes de obras cinematográficas, la Ley 1403 de 2010, o llamada también Ley Fanny Mikey, en honor a la actriz y directora que lo promovió, modificó el artículo 168 de la Ley 23 de 1982 y permitió que los artistas y actores de este tipo de obras percibieran una remuneración equitativa por la comunicación pública de sus obras audiovisuales.

Esta ley que contiene solo dos artículos, señala literalmente en el parágrafo 1:

Sin perjuicio de lo contemplado en el párrafo anterior, los artistas intérpretes de obras y grabaciones audiovisuales conservarán, en todo caso, el derecho a percibir una remuneración equitativa por la comunicación pública, incluida la puesta a disposición y el alquiler comercial al público, de las obras y grabaciones audiovisuales donde se encuentren fijadas sus interpretaciones o ejecuciones. En ejercicio de este derecho no podrán prohibir, alterar o suspender la producción o la normal explotación comercial de la obra audiovisual por parte de su productor, utilizador o causahabiente. ${ }^{95}$ Subrayado nuestro.

Este derecho, además, de acuerdo con la modificación, debe hacerse efectivo mediante las sociedades de gestión colectiva, razón por la cual la norma fue demandada ante la Corte Constitucional, que en su sentencia aclaró que:

Los intérpretes o ejecutantes de obras o grabaciones audiovisuales pueden hacer efectivos su derecho de remuneración utilizando mecanismos de cobro distintos al de la sociedad de gestión colectiva, incluyendo el cobro independiente o individual, dentro del marco de las normas legales vigentes. ${ }^{96}$

De esta forma, el recaudo se puede hacer por medio de la sociedad de gestión colectiva en Colombia llamada Actores, que obtuvo su licencia para funcionar el 28 de septiembre de $2011,{ }^{97}$ o de manera individual.

Igualmente, es importante reseñar que aunque la modificación hecha al artículo 168 de la Ley 23 de 1982, no hizo referencia a la irrenunciabilidad del derecho a percibir una remuneración por el derecho de comunicación pública, sí podría ser válido darle esa interpretación, ya que la norma utilizó la expresión conservaran, en todo caso, la cual vista a la luz de las discusiones que se plantearon en la promulgación y el espíritu de la ley, además de su acepción gramatical de expresión, podrían indicar válidamente que los artistas siempre tendrán esta prerrogativa legal, que les permita obtener algunas ganancias producto de su trabajo creativo, especialmente cuando ya se retiran por edad.

La promulgación de esta ley coincidió, casi que al mismo tiempo con la suscripción del tratado de Beijing 98 sobre interpretaciones y ejecuciones audiovisuales, adoptado el 24 de junio de 2012, y que precisamente vela por estos derechos de remuneración equitativa por los derechos de comunicación pública, ${ }^{99}$ señalados en la Ley Fanny Mikey.

\section{VIII. ¿QUÉ PASÓ CON LOS DIRECTORES Y DEMÁS AUTORES DE LA OBRA CINEMATOGRÁFICA? LEY PEPE SÁNCHEZ DE 2017}

Ya revisamos cómo el fomento de la producción cinematográfica y la evolución legislativa en Colombia han apoyado de manera importante a los productores, con el establecimiento de cargas parafiscales a las boleterías que redundan en créditos a favor de los productores y la obligación de presentar cuotas de cine nacional en las salas de exhibición. Esto ha hecho que la producción de películas nacionales haya crecido de manera exponencial en los últimos años, que más personas asistan a las proyecciones y que, por tanto, los rendimientos 
económicos para los productores sean mayores. Igualmente, la expedición de la Ley Fanny Mikey les otorgó unas prerrogativas a los artistas y actores para el reconocimiento de sus derechos de comunicación pública sobre sus interpretaciones. Ahora, consideramos que lo justo es que también los autores, en este caso los directores, se beneficien del éxito de sus obras, más cuando se trata de un trabajo sometido, como toda producción artística, a irregularidades y contingencias particulares.

Por ello, a partir de la iniciativa de la Senadora Clara Rojas, ${ }^{100}$ la plenaria del Senado de la República de Colombia, después de las discusiones en la Comisión Primera, aprobó la Ley Pepe Sánchez, en honor al famoso director de cine colombiano, el 23 de mayo de 2017, ${ }^{101}$ a fin de consagrar, en cabeza de los directores en su calidad de autores de la obra cinematográfica, y los demás autores de estas obras-, derechos patrimoniales irrenunciables sobre ellas, para que perciban una parte de las regalías generadas por la exhibición en las salas nacionales y extranjeras. Esta iniciativa fue discutida en el Senado del Congreso de la República por medio del Proyecto de Ley 218 de 2016. ${ }^{102}$

El objeto de este proyecto es modificar el artículo 98 de la Ley 23 de 1982 estableciendo lo siguiente:

Artículo 98. Los derechos patrimoniales sobre la obra cinematográfica se reconocerán, salvo estipulación en contrario a favor del productor.

Parágrafo $1^{\circ}$. No obstante la presunción de cesión de los derechos de los autores establecidos en el artículo 95 de la presente ley, conservarán el derecho irrenunciable a recibir una remuneración equitativa por los actos de comunicación pública incluida la puesta a disposición y el alquiler comercial al público que se hagan de la obra audiovisual, remuneración que será pagada directamente por quien realice la comunicación pública. [...]. (subrayas propias)

En consecuencia, esta norma se hace aplicable a los autores mencionados en el artículo 95 de la Ley 23 de 1982, es decir, a los directores, guionistas, autores de la música y dibujantes del diseño animado. Observamos entonces, que lo que pretendió el proyecto comentado es dejar inmune la presunción de que los derechos patrimoniales pertenecen al productor, estableciendo, no obstante, que los autores conservan un derecho irrenunciable a recibir una remuneración proporcional por la comunicación pública de la obra, su disposición y alquiler comercial. Esto es semejante a lo estipulado en diversas legislaciones extranjeras. La alemana, por ejemplo, determina que los autores de fotogramas tienen el derecho irrenunciable de recibir una remuneración por el alquiler de sus obras. ${ }^{103}$ En España, por ejemplo, también existe una:

[s]imilitud tanto esta presunción de cesión en favor del productor, como derecho a una remuneración equitativa en los artículos 88 y 90 de nuestro Real Decreto Legislativo $1 / 1996,{ }^{104}$ del 12 de abril, por el que se aprueba el texto refundido de la Ley de Propiedad Intelectual (TRLPI). ${ }^{105}$

Así, se ha dicho que, si bien en otros países se adeuda casi un millón de dólares a directores colombianos, no ha sido posible que tales fondos entren en su patrimonio por el vacío existente en nuestra legislación al respecto. ${ }^{106}$

Un caso importante es el de Ciro Guerra -que, a propósito, es uno de los impulsores del proyecto de Ley antes mencionado- y El abrazo de la serpiente: a pesar de haber logrado en las taquillas de Francia, donde se reconocen derechos irrenunciables a los autores, más de 1,4 millones de dólares, su director no ha recibido ninguna regalía sobre ello. ${ }^{107}$

Igualmente, la ley tiene carácter retroactivo, en lo que respecta a las cesiones de derechos que los autores hayan realizado con anterioridad a la promulgación de la norma. Es decir, que este derecho sobre la comunicación pública de las obras es irrenunciable y no contempla los demás derechos que se hubieran podido ceder los autores por alguna de las formas de transmisión del derecho de autor.

Una vez pase la sanción presidencial, es importante que se establezca una sociedad de gestión colectiva que, a pesar de no haberse incluido en la norma, como si lo fue en la Ley Fanny Mikey, sí es deseable, ya que es más sencillo realizar los cobros y obtener las regalías, fruto de la comunicación pública de las obras, especialmente del extranjero. 
Según señala el connotado director de cine Mario Mitrotti "Colombia es un gran productor y exportador de telenovelas y el público adora las historias que viajan del país al exterior. La adición a la ley significa un gran logro para todos los que hacemos parte de estas producciones”. En igual sentido, dijo Mitrotti, en 2014 la Confederación Internacional de Sociedades de Autores y Compositores (Cisac), recaudó 499 millones de euros en el mundo por comunicación pública de las obras cinematográficas, de los cuales quince millones podrían corresponder a Colombia. ${ }^{108}$ Desafortunadamente el director y guionista Pepe Sánchez, murió antes de que esta ley fuera aprobada, pero su legado trascenderá, no solamente desde lo artístico sino desde los derechos de autor.

\section{CONCLUSIONES}

Esta investigación muestra cómo después de años de abandono estatal al desarrollo de producciones audiovisuales, en los últimos 35 años ha tenido lugar una producción legislativa que ha fomentado, con apoyo financiero, la creación y consolidación del cine nacional. Así, hoy en día vemos cómo los grandes directores y películas que hoy ganan premios en festivales internacionales, logran realizar sus obras.

Es cierto que a partir de la expedición de la Ley de Cine se ha apoyado la producción seria de cine y de hecho ha mejorado su calidad. Acabamos de observar cuántas dificultades han pasado los productores a lo largo de la historia colombiana, para financiar y llevar adelante sus obras. Por ello, consideramos necesario realizar un recuento histórico de las condiciones en que se desarrollaba cine en el siglo XX porque solo así se logra vislumbrar el valor de las leyes 814 de 2003 y 1556 de 2012.

Igualmente, los diferentes logros obtenidos a partir de la expedición de las dos leyes mencionadas justifican la inversión y el interés público por la producción de largometrajes y cortometrajes. No obstante, es preciso advertir, es injusto que los beneficios económicos que generan las leyes de promoción de cine solamente se dirijan a los productores, porque no se encuentra este apoyo estatal complementado en medidas legislativas que les permitan a los autores de la industria cultural cinematográfica disfrutar patrimonialmente del éxito de sus creaciones. Igualmente, estas leyes han estado acompañadas de la protección que el derecho de autor ha otorgado a las obras cinematográficas, desde la misma Constitución de 1886 y que tuvo un avance muy importante con la expedición de la Ley 23 de 1982.

Por todo lo anterior, celebramos el Proyecto de Ley 218 de 2016, que fue aprobado el 23 de mayo de 2017 por la Plenaria del Senado y está pendiente de sanción presidencial, porque permitirá a los autores de las obras cinematográficas, una vez se convierta en Ley de la República, recibir ingresos permanentes sobre las obras en las que participan, sin que su participación esté supeditada al consentimiento de quien financia el proyecto. Esto, no solamente mejorará la calidad de vida de los autores sino que incentivará el mejoramiento de la calidad de nuestro cine al darle al director, por ejemplo, un poco más de libertad para definir sus temas, al no estar atado exclusivamente a la aquiescencia de un productor. Es que es, tal vez, injusto que, directores como Ciro Guerra y César Acevedo, que le han dado al país los mayores reconocimientos por sus obras cinematográficas, no puedan percibir las regalías que se generan por su exhibición en otros países, porque en Colombia aún no se reconoce este derecho.

Aún falta un largo camino por recorrer, ya que hay otros creativos de las obras audiovisuales a los que se les reconocen derechos sobre la obra audiovisual como los directores de cámaras, sonido, fotografía, pero seguramente las tendencias autorreferenciales ${ }^{109}$ del derecho nos llevarán a la inclusión de estos creativos dentro del sistema de derecho de autor. Esto, sin duda, promoverá la industria del cine en nuestro país y seguramente tendremos mayor inversión extranjera en la materia. ${ }^{110}$ 


\section{Agradecimientos}

Artículo fruto del desarrollo del proyecto de investigación del grupo en derecho privado y propiedad intelectual (GEPPI) de la Facultad de Derecho de la Universidad Católica de Colombia en colaboración con la Facultad de Derecho, Ciencias Políticas y Sociales de la Universidad Nacional de Colombia.

\section{BIBLIOGRAFÍA. Libros}

ANTEQUERA PARILLI, RICARDO, Estudios de derecho industrial y derecho de autor. Derecho de autor y derechos conexos en el entorno digital (Temis-Editorial Universidad Javeriana, Bogotá, 2009).

BECERRA, JAIRO, COTINO, LORENZO, GARCÍA VARGAS, CLAUDIA BIBIANA, SÁNCHEZ ACEVEDO, MARCO EMILIO \& TORRES ÁVILA, JHEISON, La responsabilidad del estado por la utilización de tecnologias de información y la comunicación. (Universidad Católica de Colombia, Bogotá, 2015).

CANAVAL, JUAN PABLO, Manual de propiedad intelectual (Universidad del Rosario, Bogotá, 2008).

FLÓREZ, GERMÁN, Curso de derecho de autor para la industria audiovisual (Dirección Nacional de Derecho de Autor, Bogotá, 2012).

Fundación Patrimonio Fílmico Colombiano. Historia del cine colombiano: 1897-2008, 10 (Fundación Patrimonio Fílmico Colombiano, Bogotá, 2009).

MÁRQUEZ ROBLEDO, SANTIAGO, Principios generales del derecho de autor, 73 (Pontificia Universidad Javeriana, Bogotá, 2004).

Ministerio de Cultura, Cartilla de historia del cine colombiano (Ministerio de Cultura, Bogotá, 2015).

Ministerio de Cultura, Compendio de políticas culturales (Ministerio de Cultura, Bogotá, 2010).

MONTOYA, SANDRA, Política exterior y diplomacia cultural. Hacia Colombia en posconflicto (Universidad Católica de Colombia, Bogotá, 2017).

MOYA, MANUEL Y BERNAL, CARLOS. Fundamentos semióticos para la investigación jurídica (Universidad Católica de Colombia, Bogotá, 2017).

MONROY, JUAN CARLOS, Derechos de autor y derechos conexos (Autores editores, 2013).

OLARTE, JORGE MARIO Y ROJAS, MIGUEL ÁNGEL, Manual de derecho de autor para alcaldias y gobernaciones (Dirección Nacional de Derecho de Autor, Bogotá, 2011).

OLENKA, WOOLCOTT \& GERMÁN FLÓREZ, Protección del derecho de autor. Implicaciones del TLC entre Colombia y Estados Unidos (Astrea, Buenos Aires, Universidad Católica de Colombia, Bogotá, 2015).

PABÓN, JHONNY, De los privilegios a la propiedad intelectual. La protección en Colombia a las obras literarias, artísticas y cientificas en el siglo XIX, 179-200 (Universidad Externado de Colombia, Bogotá, 2010).

QUATERSEN, ALESSANDRA, ROMIS MÓNICA \& LANZAFAME, FRANCESCO, Las industrias culturales en América Latina y el Caribe: desafios y oportunidades. (BID, Washington, 2007). Disponible en: http://idbdo cs.iadb.org/wsdocs/getdocument.aspx?docnum $=1156415$

RÍOS, WILSON, La propiedad intelectual en la era de las tecnologías. Aspectos generales del derecho de autor y derechos conexos (Universidad de los Andes-Temis, Bogotá, 2011).

RODRÍGUEZ ESCOBAR, VIANA, Derecho de autor en el ámbito audiovisual y su aplicación al entorno digital en seis paises de América Latina (Ministerio de Cultura de Colombia-Proimágenes-Banco Interamericano de Desarrollo [BID], Bogotá, Colombia. 2015). Disponible en: http://www.mincultura.gov.co/areas/cinematografia/public aciones/Documents/Derecho\%20de\%20Autor\%20-\%20V.\%20RODRIGUEZ.pdf.

ROJAS, CARLOS ALBERTO, Concepto 1-2008-6988, aplicación de la ley de derecho de autor en el tiempo y en el espacio (Dirección Nacional de Derecho de Autor, Bogotá, 2008).

ROJAS, CARLOS ALBERTO, Concepto Aplicación de la ley de derecho de autor en el tiempo y en el espacio. Concepto 1-2006-3200 (Dirección Nacional de Derecho de Autor, Bogotá, 2006). 
SALCEDO SILVA, HERNANDO, Crónicas del cine colombiano: 1887-1950 (Carlos Valencia Editores, Bogotá, 1981).

SANTA, EDUARDO, Régimen depropiedad intelectualy prensa (Ministerio de Gobierno, Imprenta Nacional, Bogotá, 1962).

TOBÓN, NATALIA \& VARELA, EDUARDO, Derecho de autor para creativos (Grupo Editorial Ibáñez, Bogotá 2010).

TORRES RUBIO, FELIPE, Conozca y proteja sus derechos de autor: aspectos relativos a la obra audiovisual (Ministerio de Cultura-Fondo Mixto de Promoción Cinematográfica-Proimágenes-Universidad Nacional de Colombia, Bogotá, 2003).

VEGA JARAMILLO, MANUEL, Manual de derecho de autor (Dirección Nacional de Derecho de Autor-Alcaldía Mayor de Bogotá, Bogotá, 2010).

ZAPATA LÓPEZ, FERNANDO, El derecho de autor y los derechos conexos: contenido y ejercicio de los derechos, 7 (Organización Mundial de Propiedad Intelectual [OMPI], Honduras, 2000).

ZULUAGA, PEDRO ADRIÁN, Cine colombiano: cánones y discursos dominantes. Cinemateca Distrital (Instituto Distrital de las Artes [Idartes], Alcaldía Mayor de Bogotá, Bogotá, 2011).

\section{BIBLIOGRAFÍA. Revistas}

CONTRERAS-JARAMILLO, JUAN CAMILO, Origen y sustento del agotamiento de los derechos de propiedad intelectual, 131 Vniversitas, 277-322 (2015). Disponible en: http://dx.doi.org/10.11144/Javeriana.vj131.osad

DÍAZ, JUAN \& HAMMAN, ALEJANDRA, Una mirada al cine colombiano. Revista Razón y Palabra (noviembre 2011-enero 2012). Disponible en: http://www.razonypalabra.org.mx/N/N78/09_DiazHamman_M78.pdf

HERNANDO COLLAZOS, ISABEL, Aproximación del derecho de autor al arte performativo, RIIPAC, 5-6, 18 (2015). Disponible en: http://www.eumed.net/rev/riipac

ORDELIN-FONT, JORGE LUIS, El contrato de gestión de los representantes de los artistas intérpretes y ejecutantes musicales. Un estudio desde el ordenamiento jurídico cubano, 131 Vniversitas, 391-432 (2015). Disponible en: http://dx.doi.org/10.11144/Javeriana.vj131.cgra

PABÓN, JHONNY, Aproximación de la historia del derecho de autor: antecedentes normativos. Revista de la propiedad inmaterial, (2009). Disponible en: https://www.minjusticia.gov.co/InvSocioJuridica/DboRegistros/GetPdf?fi leName=Aproximacion\%20a\%20la\%20historia\%20del\%20derecho\%20de\%20autor.pdf

SANABRIA, LUIS EDUARDO, Conceptualización jurídica del plagio en Colombia. Rev Colomb Cir., 29, 88-97 (2014).

TAMAYO CAMILO, Hacia una arqueología de nuestra imagen: cine y modernidad en Colombia (1900-1960), Signo y Pensamiento 48, XXV (enero-junio), 45 (2006). Disponible en: http://www.uacm.kirj.redalyc.redalyc.org/ar ticulo.oa?id $=86004803$

\section{BIBLIOGRAFIA. Normatividad colombiana}

Colombia, Ley 1556 de 2012, por la cual se fomenta el territorio nacional como escenario para el rodaje de obras cinematográficas, 48486 Diario Oficial, 9 de julio de 2012.

Colombia, Ley 1403 de 2010, por la cual se adiciona la Ley 23 de 1982, sobre derechos de autor, se establece una remuneración por comunicación pública a los artistas, intérpretes o ejecutantes de obras y grabaciones audiovisuales o "Ley Fanny Mikey", 47.775 Diario Oficial, 19 de julio de 2010.

Colombia, Ley 814 de 2003, por la cual se dictan normas para el fomento de la actividad cinematográfica en Colombia, 45237 Diario Oficial, 3 de julio de 2003.

Colombia, Ley 23 de 1982, sobre derechos de autor, 35949 Diario Oficial, 28 de enero de 1982. 
Colombia, Ley 86 de 1946, sobre propiedad intelectual, 26317 Diario Oficial, 26 de diciembre de 1946. Disponible en: http://www.suin-juriscol.gov.co/viewDocument.asp?id=1791036

Colombia, Ley 9 de 1942, por la cual se fomenta la industria cinematográfica, 25051 Diario Oficial, 31 de agosto de 1942. Disponible en: http://www.suin-juriscol.gov.co/clp/contenidos.dll/Leyes/1564366?fn=document-fram e.htm $\$ \mathrm{f}=$ templates $\$ 3.0$

Colombia, Ley 32 de 1886, sobre propiedad literaria y artística, 6842 Diario Oficial, 28 de octubre de 1886.

ROJAS, ClARA, Proyecto de Ley 218 de 2016, Comisión Primera del Congreso de la República. Disponible en: http://directorescolombia.com.co/wp-content/uploads/2016/09/PL-2016-N218C-Comision_Primera-L EY_PEPE_SANCHEZ.pdf

\section{BIBLIOGRAFIA. Jurisprudencia colombiana}

Colombia, Corte Constitucional, Sala Plena, Sentencia C-911 de 2011, Expedientes D-8534, D-8535 y D-8548 (acumulados), magistrado ponente: Mauricio González Cuervo.

Colombia, Corte Constitucional, Sala Plena, Sentencia C-276 de 1996, Expediente D-1163, magistrado ponente: Julio César Ortiz Gutiérrez.

Colombia, Corte Constitucional, Sala Plena, Sentencia C-155 de 1995, Expedientes D-1797, D-1809, D-1813 y D-1818, magistrado ponente: Vladimiro Naranjo.

Código Civil colombiano. Artículo 671. Disponible en: http://www.secretariasenado.gov.co/senado/basedoc/codig o_civil_pr020.html

Colombia, Consejo de Estado, Sala de lo Contencioso Administrativo, Sección Tercera, Sentencia 3060, consejero ponente: Carlos Betancur Jaramillo, 18 de marzo de 1991.

Colombia, Corte Suprema de Justicia, Sala Plena, magistrado ponente: Humberto Barrera Domínguez.

\section{BIBLIOGRAFIA. Documentos y tesis}

AgUAYO, MIGUEL, La Comisión Primera del Senado aprueba la Ley Pepe Sánchez. Instituto Autor, España (2016). Disponible en: http://hemeroteca.institutoautor.org/story/La-Comisin-Primera-del-Senado-de-Colombia-apr ueba-la-Ley-Pepe-Snchez-_4553.

LIPSZYC DELIA, La protección internacional de los derechos de autor y los derechos conexos. Seminario Internacional de la Organización Mundial de Propiedad Intelectual (OMPI). 14 y 15 de abril de 1997, Caracas, Venezuela.

Ministerio de Cultura, Ley Filmación Colombia ha generado ingresos al pais por más de \$86 mil millones. Disponible en: http://www.mincultura.gov.co/prensa/noticias/Paginas/Ley-Filmaci\%C3\%B3n-Colombia--ha-generado-i ngresos-al-pa\%C3\%ADs-por-m\%C3\%A1s-de-86-mil-millones.aspx

\section{BIBLIOGRAFIA. Medios de comunicación}

La tierra y la sombra, del colombiano Cesar Acevedo, mejor ópera prima en Cannes, Agencia EFE, 24 mayo, 2015. Disponible en: http://www.efe.com/efe/america/cultura/la-tierra-y-sombra-del-colombiano-acevedo-mejor-o pera-prima-en-cannes/20000009-2621438

Ciro Guerra, el colombiano nominado al Óscar: 'Es el momento de revelar elpaís oculto, la Colombia de la que no se habla', BBC Mundo, 25 enero, 2016. Disponible en: http://www.bbc.com/mundo/noticias/2016/01/160122_colom bia_oscars_nominada_mejor_pelicula_extranjera_abrazo_serpiente_ciro_guerra_lv

El cine colombiano ratifica su buen momento con cifras récord, Dinero, 28 enero 2016. Disponible en: http://www.dine ro.com/actualidad/articulo/las-peliculas-mas-vistas-del-2015-en-colombia/218560 
Colombia Magia Salvaje es la película más vista en la historia del cine colombiano, Revista Semana, 8 octubre, 2015. Disponible en: http://sostenibilidad.semana.com/medio-ambiente/articulo/colombia-magia-salvaje-peli cula-mas-vista-historia-del-cine-colombiano/33957

Las 20 películas colombianas más taquilleras de la historia, Portal Terra Colombia. Disponible en: https://www.terra.com.co/entretenimiento/cine/las-20-peliculas-colombianas-mas-taquillerasde-la-historia,781965ffb18ef310VgnVCM5000009ccceb0aRCRD.html.

Ley Pepe Sánchez quedó pendiente de sanción presidencial, Diario el Tiempo (24 de mayo de 2017). Disponible en: http://www.eltiempo.com/cultura/musica-y-libros/aprueban-ley-pepe-sanchez-que-protege-a-directores-y -guionistas-91506

Diez canciones memorables del cine colombiano. Señal Colombia. Disponible en: http://www.senalcolombia.tv/cin e/noticias/diez-canciones-memorables-del-cine-colombiano.

Revive proyecto de Ley Pepe Sánchez, Portafolio, (15 marzo, 2016). Disponible en: http://www.portafolio.co/negocios /empresas/revive-proyecto-ley-pepe-sanchez-derechos-autor-directores-audiovisuales-492567

Van 25 peliculas internacionales en Colombia, La silla llena. Disponible en: http://lasillavacia.com/silla-llena/red-lide $\mathrm{r} /$ historia/van-25-peliculas-internacionales-en-colombia-58897

\section{BIBLIOGRAFIA. Tratados internacionales}

Organización Mundial de Propiedad Intelectual, Convenio de Berna para la Protección de obras artísticas y literarias. Artículo 7. Disponible en: http://www.wipo.int/treaties/es/text.jsp?file_id=283698\#P94_12427

Convenio de Berna para la Protección de Obras artísticas y literarias. Organización Mundial de Propiedad Intelectual de 1886.

Decisión Andina 351 de 1993

Tratado de la OMPI de Derecho de Autor de 1996. (TODA).

Tratado OMPI sobre Interpretación o Ejecución y Fonogramas de 1996. (TOIEF).

Tratado de Beijing sobre interpretaciones y ejecuciones audiovisuales de 2012.

\section{BIBLIOGRAFIA. Otros}

Actores, Sociedad Colombiana de Gestión, Comunidad Camaleón. Disponible en: http://www.actores.org.co/quien es-somos

Guilliam v. American Broadcasting Companies Inc., 538. F2D 14, 1976. U.S. App. LEXIS 8225, 192 U.S.P.Q. (BNA).

Ciudad delirio. Tráiler oficial (2014). Disponible en: https://www.youtube.com/watch?v=hdEHgQ_-ThI\&list=PL avON3cGG4BOlmPar9mft8NpdOaGnmSQh\&index=2

WILLIAMS, JOHN, Imperial March. Star Wars. Disponible en: https://www.youtube.com/watch?v=bQP-b30n2xo

\section{Notas}

* Artículo de investigación

1 Ciro Guerra, el colombiano nominado al Óscar: 'Es el momento de revelar el país oculto, la Colombia de la que no se habla', BBC Mundo, 25 enero, 2016. Disponible en: http://www.bbc.com/mundo/noticias/2016/01/160122_colombia_oscars_nominada_ mejor_pelicula_extranjera_abrazo_serpiente_ciro_guerra_lv

2 La tierra y la sombra, del colombiano Cesar Acevedo, mejor ópera prima en Cannes, Agencia EFE, 24 mayo, 2015. Disponible en: http://www.efe.com/efe/america/cultura/la-tierra-y-sombra-del-colombiano-acevedo-mejor-opera-prima-en-cannes/20000 $009-2621438$ 
3 Colombia Magia Salvaje es la película más vista en la historia del cine colombiano, Revista Semana, 8 octubre, 2015. Disponible en: http://sostenibilidad.semana.com/medio-ambiente/articulo/colombia-magia-salvaje-pelicula-mas-vista-historia-del-cine-col ombiano/33957

4 El cine colombiano ratifica su buen momento con cifras récord, Dinero, 28 enero 2016. Disponible en: http://www.dinero.co $\mathrm{m} /$ actualidad/articulo/las-peliculas-mas-vistas-del-2015-en-colombia/218560

5 Específicamente el 14 de abril de 1897, presentada como "La función del vitascopio, de Edison, un instrumento nunca antes presentado en el istmo, la cual tendrá lugar a las 8 p.m., en el edificio James \& Coy, en la esquina de las calles Fronty Sexta". Fundación Patrimonio Fílmico Colombiano, Historia del cine colombiano: 1897-2008, 10 (Fundación Patrimonio Fílmico Colombiano, Bogotá, 2009). Disponible en: http://cine.8manos.in/wp-content/uploads/HISTORIA-CINE-COLOMBIANO-230312.pd $\mathrm{f}$

6 Fundación Patrimonio Fílmico Colombiano, Historia del cine colombiano: 1897-2008, 10 (Fundación Patrimonio Fílmico Colombiano, Bogotá, 2009). Disponible en: http://cine.8manos.in/wp-content/uploads/HISTORIA-CINE-COLOMBIANO -230312.pdf

7 CAMILO TAMAYO, Hacia una arqueología de nuestra imagen: cine y modernidad en Colombia (1900-1960), Signo y Pensamiento 48, XXV (enero-junio), 45 (2006). Disponible en: http://www.uacm.kirj.redalyc.redalyc.org/articulo.oa?id=8600 4803

8 Fundación Patrimonio Fílmico Colombiano, Historia del cine colombiano: 1897-2008, 11 (Fundación Patrimonio Fílmico Colombiano, Bogotá, 2009).

9 Fundación Patrimonio Fílmico Colombiano, Tiempos del Olympia, 54 (Fundación Patrimonio Fílmico Colombiano, Bogotá, 1992).

10 Fundación Patrimonio Fílmico Colombiano, Tiempos del Olympia, 59 (Fundación Patrimonio Fílmico Colombiano, Bogotá, 1992).

11 Considerado el más antiguo registro de cine de producción nacional. Fundación Patrimonio Fílmico Colombiano. Historia del cine colombiano: 1897-2008, 12 (Fundación Patrimonio Fílmico Colombiano, Bogotá, 2009).

12 PEDRO ADRIÁN ZULUAGA, Cine colombiano: cánones y discursos dominantes. Cinemateca Distrital. (Instituto Distrital de las Artes [Idartes], 79 (Alcaldía Mayor de Bogotá, Bogotá, 2011).

13 Fundación Patrimonio Fílmico Colombiano, Historia del cine colombiano: 1897-2008, 13 (Fundación Patrimonio Fílmico Colombiano, Bogotá, 2009).

14 HERNANDO SALCEDO SILVA, Crónicas del cine colombiano: 1887-1950,47 (Carlos Valencia Editores, Bogotá, 1981).

15 CAMILO TAMAYO, Hacia una arqueologia de nuestra imagen: cine y modernidad en Colombia (1900-1960), Signo y Pensamiento 48, XXV (enero-junio), 45 (2006). Disponible en: http://www.uacm.kirj.redalyc.redalyc.org/articulo.oa?id=8600 4803

16 CAMILO TAMAYO, Hacia una arqueologia de nuestra imagen: cine y modernidad en Colombia (1900-1960), Signo y Pensamiento 48, XXV (enero-junio), 45 (2006). Disponible en: http://www.uacm.kirj.redalyc.redalyc.org/articulo.oa?id=8600 4803

17 HERNANDO SALCEDO SILVA, Crónicas del Cine Colombiano:1887-1950, 14 (Carlos Valencia Editores, Bogotá, 1981).

18 Ministerio de Cultura, Cartilla de historia del cine colombiano, 5 (Ministerio de Cultura, dirección de Cinematografía, Bogotá, 2015).

19 Fundación Patrimonio Fílmico Colombiano, Historia del cine colombiano: 1897-2008, 15 (Fundación Patrimonio Fílmico Colombiano, Bogotá, 2009).

20 Ministerio de Cultura, Cartilla de historia del cine colombiano, 6 (Ministerio de Cultura, dirección de Cinematografía, Bogotá, 2015). 
21 HERNANDO SALCEDO SILVA, Crónicas del cine colombiano: 1887-1950, 105-106 (Carlos Valencia Editores, Bogotá, 1981).

22 LUIS EDUARDO SANABRIA, Conceptualización jurídica del plagio en Colombia, Rev Colomb Cir., 29, 88-97 (2014).

23 Colombia, Corte Constitucional, Sala Plena, Sentencia C-276 de 1996, Expediente D-1163, magistrado ponente: Julio César Ortiz Gutiérrez. Intervención del director Fernando Zapata López, director de la Dirección Nacional de Derecho de Autor.

24 CARLOS ALBERTO ROJAS, Concepto 1-2008-6988, aplicación de la ley de derecho de autor en el tiempo y en el espacio (Dirección Nacional de Derecho de Autor, Bogotá, 2008).

25 SANTIAGO MÁRQUEZ ROBLEDO, Principios generales del derecho de autor 73 (Pontificia Universidad Javeriana, Bogotá, 2004).

26 DELIA LIPSZYC, La protección internacional de los derechos de autor y los derechos conexos. Seminario Internacional de la Organización Mundial de Propiedad Intelectual (OMPI). 14 y 15 de abril de 1997, Caracas, Venezuela.

27 JUAN DÍAZ Y ALEJANDRA HAMMAN, Una mirada al cine colombiano, Revista Razón y Palabra, 78 (noviembre 2011 enero 2012). Disponible en: http://www.razonypalabra.org.mx/N/N78/09_DiazHamman_M78.pdf

28 JHONNY PABÓN, De los privilegios a la propiedad intelectual. La protección en Colombia a las obras literarias, artísticas y cientificas en el siglo XIX, 179-200 (Universidad Externado de Colombia, Bogotá, 2010).

29 JHONNY PABÓN, Aproximación de la historia del derecho de autor: antecedentes normativos, Revista de la propiedad inmaterial, 94 (2009). Disponible en: https://www.minjusticia.gov.co/InvSocioJuridica/DboRegistros/GetPdf?fileName=Apro ximacion\%20a\%20la\%20historia\%20del\%20derecho\%20de\%20autor.pdf

30 Organización Mundial de Propiedad Intelectual, Convenio de Berna para la Protección de obras artísticas y literarias. Artículo 7. Disponible en: http://www.wipo.int/treaties/es/text.jsp?file_id=283698\#P94_12427

31 Código Civil colombiano. Artículo 671. Disponible en: http://www.secretariasenado.gov.co/senado/basedoc/codigo_civ il_pr020.html

32 SANTIAGO MÁRQUEZ ROBLEDO, Principios generales del derecho de autor, 73 (Pontificia Universidad Javeriana. Bogotá, 2004).

33 Fundación Patrimonio Fílmico Colombiano, Historia del cine colombiano: 1897-2008, 38 (Fundación Patrimonio Fílmico Colombiano, Bogotá, 2009).

34 Colombia, Ley 9 de 1942, por la cual se fomenta la industria cinematográfica, Artículo 4, 25051 Diario Oficial, 31 de agosto de 1942. Disponible en: http://www.suin-juriscol.gov.co/clp/contenidos.dll/Leyes/1564366?fn=document-frame.htm $\$ f=$ temp lates $\$ 3.0$

35 Colombia, Ley 9 de 1942, Artículo 5, por la cual se fomenta la industria cinematográfica, 25051 Diario Oficial, 31 de agosto de 1942. Disponible en: http://www.suin-juriscol.gov.co/clp/contenidos.dll/Leyes/1564366?fn=document-frame.htm $\$ f=$ temp lates $\$ 3.0$

36 Fundación Patrimonio Fílmico Colombiano, Historia del cine colombiano: 1897-2008, 63 (Fundación Patrimonio Fílmico Colombiano, Bogotá, 2009).

37 Recuérdese que el objeto de la primera película sonora, La apoteosis de Enrique Olaya Herrera fue documentar la vida y muerte del expresidente colombiano.

38 Ministerio de Cultura, Cartilla de historia del cine colombiano, 6 (Ministerio de Cultura, dirección de Cinematografía, Bogotá, 2015).

39 Fundación Patrimonio Fílmico Colombiano, Historia del cine colombiano: 1897-2008, 32 (Fundación Patrimonio Fílmico Colombiano, Bogotá, 2009).

40 Fundación Patrimonio Fílmico Colombiano, Historia del cine colombiano: 1897-2008, 38-39 (Fundación Patrimonio Fílmico Colombiano, Bogotá, 2009). 
41 Fundación Patrimonio Fílmico Colombiano, Historia del cine colombiano: 1897-2008, 44 (Fundación Patrimonio Fílmico Colombiano, Bogotá, 2009).

42 Ministerio de Cultura, Cartilla de historia del cine colombiano, 9-11 (Ministerio de Cultura, dirección de Cinematografía, Bogotá, 2015).

43 Ministerio de Cultura, Cartilla de historia del cine colombiano, 12 (Ministerio de Cultura, dirección de Cinematografía, Bogotá, 2015).

44 SANTIAGO MÁRQUEZ ROBLEDO, Principios generales del derecho de autor, 73 (Pontificia Universidad Javeriana, Bogotá, 2004).

45 EDUARDO SANTA, Régimen depropiedad intelectualy prensa (Ministerio de Gobierno, Imprenta Nacional, Bogotá, 1962). SANTIAGO MÁRQUEZ ROBLEDO, Principios generales del derecho de autor, 74 (Pontificia Universidad Javeriana, Bogotá, 2004).

46 JUAN PABLO CANAVAL, Manual de propiedad intelectual (Universidad del Rosario, Bogotá, 2008).

47 Colombia, Consejo de Estado, Sala de lo Contencioso Administrativo, Sección Tercera, Sentencia 3060, consejero ponente: Carlos Betancur Jaramillo, 18 de marzo de 1991.

48 Colombia, Consejo de Estado, Sala de lo Contencioso Administrativo, Sección Tercera, Sentencia 3060, consejero ponente: Carlos Betancur Jaramillo, 18 de marzo de 1991.

49 Colombia, Corte Suprema de Justicia, Sala Plena, magistrado ponente: Humberto Barrera Domínguez. (Demanda de inconstitucionalidad contra el artículo 39 de la Ley 86 de 1946). Disponible en: http://derechodeautor.gov.co/documents/1018 1/216828/Corte+Suprema+de+Justicia\%2C\%20Sala+Plena\%2C\%20Sentencia+del+10+de+febrero+de+1960.pdf

50 Colombia, Ley 86 de 1946, artículos 6 y 12, sobre propiedad intelectual, 26317 Diario Oficial, 26 de diciembre de 1946. Disponible en: http://www.suin-juriscol.gov.co/viewDocument.asp?id=1791036

51 Colombia, Ley 86 de 1946, artículos 30 y 31, sobre propiedad intelectual, 26317.30, Diario Oficial, 26 de diciembre de 1946. Disponible en: http://www.suin-juriscol.gov.co/viewDocument.asp?id=1791036

52 OLENKA, WOOLCOTT \& GERMÁN FLÓREZ, Protección del derecho de autor. Implicaciones del TLC entre Colombia y Estados Unidos, 94 (Astrea, Buenos Aires, Universidad Católica de Colombia, Bogotá, 2015).

53 Colombia, Ley 86 de 1946, artículo 32, sobre propiedad intelectual, 26317. 30, Diario Oficial, 26 de diciembre de 1946. Disponible en: http://www.suin-juriscol.gov.co/viewDocument.asp?id=1791036

54 Colombia, Ley 86 de 1946, artículo 43, sobre propiedad intelectual, 26317. 30, Diario Oficial, 26 de diciembre de 1946. Disponible en: http://www.suin-juriscol.gov.co/viewDocument.asp?id=1791036

55 Ministerio de Cultura, Compendio de políticas culturales, 503 (Ministerio de Cultura, Bogotá, 2010).

56 Fundación Patrimonio Fílmico Colombiano, Historia del cine colombiano: 1897-2008, 69 (Fundación Patrimonio Fílmico Colombiano, Bogotá, 2009).

57 Ministerio de Cultura, Compendio de políticas culturales (Ministerio de Cultura, Bogotá, 2010).

58 Ministerio de Cultura, Compendio de políticas culturales, 504 (Ministerio de Cultura, Bogotá, 2010).

59 GERMÁN FLÓREZ, Curso de derecho de autor para la industria audiovisual, 23 (Dirección Nacional de Derecho de Autor, Bogotá, 2012).

60 ALESSANDRA, QUATERSEN, MÓNICA ROMIS \& FRANCESCO LANZAFAME, Las industrias culturales en América Latina y el Caribe: desafíos y oportunidades (BID, Washington, 2007). Disponible en: http://idbdocs.iadb.org/wsdocs/ getdocument.aspx?docnum $=1156415$

61 FELIPE RUBIO TORRES, Conozca y proteja sus derechos de autor: aspectos relativos a la obra audiovisual, 36 (Ministerio de Cultura-Fondo Mixto de Promoción Cinematográfica-Proimágenes-Universidad Nacional de Colombia, Bogotá, 2003). 
CARLOS ALBERTO ROJAS, Concepto 1-2006-3200, aplicación de la ley de derecho de autor en el tiempo y en el espacio (Dirección Nacional de Derecho de Autor, Bogotá, 2006).

62 VIANA RODRÍGUEZ ESCOBAR, Derecho de autor en el ámbito audiovisual y su aplicación al entorno digital en seis paises de América Latina, 12 (Ministerio de Cultura de Colombia-Proimágenes-Banco Interamericano de Desarrollo [BID], Bogotá, Colombia. 2015). Disponible en: http://www.mincultura.gov.co/areas/cinematografia/publicaciones/Documents/Derecho\%2 0de\%20Autor\%20-\%20V.\%20RODRIGUEZ.pdf

63 FERNANDO ZAPATA LÓPEZ, El derecho de autor y los derechos conexos: contenido y ejercicio de los derechos, 7 (Organización Mundial de Propiedad Intelectual [OMPI], Honduras, 2000).

64 GERMÁN FLÓREZ, Curso de derecho de autor para la industria audiovisual, 59 (Dirección Nacional de Derecho de Autor, Bogotá, 2012).

65 Las 20 películas colombianas más taquilleras de la historia, Portal Terra Colombia. Disponible en: https://www.terra.com.co/entretenimiento/cine/las-20-peliculas-colombianas-mas-taquilleras-de-lahistoria,781965ffb18ef310VgnVCM5000009ccceb0aRCRD.html

66 Colombia, Corte Constitucional, Sala Plena, Sentencia C-155 de 1995, Expedientes D-1797, D-1809, D-1813 y D-1818, magistrado ponente: Vladimiro Naranjo.

67 Guilliam v. American Broadcasting Companies Inc., 538. F2D 14, 1976. U.S. App. LEXIS 8225, 192 USPQ. (BNA).

68 NATALIA TOBÓN \& EDUARDO VARELA, Derecho de autor para creativos, 175 (Grupo Editorial Ibáñez, Bogotá, 2010).

69 NATALIA TOBÓN Y EDUARDO VARELA, Derecho de autor para creativos, 175 (Grupo Editorial Ibáñez, Bogotá 2010).

70 MANUEL VEGA JARAMILLO, Manual de derecho de autor, 28-29 (Dirección Nacional de Derecho de Autor-Alcaldía Mayor de Bogotá, Bogotá, 2010).

71 JUAN CARLOS MONROY, Derechos de autor y derechos conexos, 65 (Autores editores, 2013).

72 JORGE MARIO OLARTE \& MIGUEL ÁNGEL ROJAS, Manual de derecho de autor para alcaldias y gobernaciones (Dirección Nacional de Derecho de Autor, Bogotá, 2011).

73 JUAN CAMILO CONTRERAS-JARAMILLO, Origen y sustento del agotamiento de los derechos de propiedad intelectual, 131 Vniversitas, 277-322 (2015). Disponible en: http://dx.doi.org/10.11144/Javeriana.vj131.osad

74 OLENKA WOOLCOTT \& GERMÁN D. FLÓREZ, El régimen de exención de responsabilidad de los ISP por infracciones de propiedad intelectual en el TLC Colombia-Estados Unidos: una explicación a partir de la DMCA y la DCE, 129 Vniversitas, 385-416 (2014). Disponible en http://dx.doi.org/10.11144/Javeriana.VJ129.reri

75 JAIRO BECERRA, LORENZO COTINO, CLAUDIA BIBIANA GARCÍA VARGAS, MARCO EMILIO SÁNCHEZ ACEVEDO \& JHEISON TORRES ÁVILA. La responsabilidad del Estado por la utilización de tecnologías de información y la comunicación (Universidad Católica de Colombia, Bogotá, 2015).

76 RICARDO ANTEQUERA PARILLI, Estudios de derecho industrial y derecho de autor. Derecho de autory derechos conexos en el entorno digital, 619 (Temis-Editorial Universidad Javeriana, Bogotá, 2009).

77 Artículo 8 del Tratado de la OMPI de Derecho de Autor de 1996 (TODA).

78 WILSON RÍOS, La propiedad intelectual en la era de las tecnologías. Aspectos generales del derecho de autor y derechos conexos (Universidad de los Andes-Temis, Bogotá, 2011).

79 GERMÁN FLÓREZ, Curso de derecho de autorpara la industria audiovisual, 59 (Dirección Nacional de Derecho de Autor, Bogotá, 2012).

80 JOHN WILLIAMS, Imperial March. Star Wars. Disponible en: https://www.youtube.com/watch?v=bQP-b30n2xo 
81 Ciudad delirio. Tráiler oficial (2014). Disponible en: https://www.youtube.com/watch?v=hdEHgQ_ThI\&list=PLavON 3cGG4BOlmPar9mft8NpdOaGnmSQh\&index=2

82 Diez canciones memorables del cine colombiano. Señal Colombia. Disponible en: http://www.senalcolombia.tv/cine/notici as/diez-canciones-memorables-del-cine-colombiano.

83 CARLOS ALBERTO ROJAS, Concepto 1-2006-3200 sobre obras audiovisuales (Dirección Nacional de Derecho de Autor de Colombia, Bogotá, 2006).

84 Colombia se hizo miembro del Convenio de Berna a partir de 1987 con la expedición de la Ley 33.

85 Artículo 34 Decisión Andina 351 de 1993.

86 ISABEL HERNANDO COLLAZOS, Aproximación del derecho de autor al arte performativo, RIIPAC, 5-6, 18 (2015). Disponible en: http://www.eumed.net/rev/riipac

87 Fundación Patrimonio Fílmico Colombiano, Historia del cine colombiano: 1897-2008, 87 (Fundación Patrimonio Fílmico Colombiano, Bogotá, 2009).

88 Ministerio de Cultura, Compendio de politicas culturales, 506 (Ministerio de Cultura, Bogotá, 2010).

89 Colombia, Ley 814 de 2003, artículos 14 y 15, por la cual se dictan normas para el fomento de la actividad cinematográfica en Colombia, 45237 Diario Oficial, 3 de julio de 2003.

90 Colombia, Ley 814 de 2003, artículo 16, por la cual se dictan normas para el fomento de la actividad cinematográfica en Colombia, 45237 Diario Oficial, 3 de julio de 2003.

91 Ministerio de Cultura, Ley Filmación Colombia ha generado ingresos al país por más de $\$ 86$ mil millones. Disponible en: http://www.mincultura.gov.co/prensa/noticias/Paginas/Ley-Filmaci\%C3\%B3n-Colombia--ha-generado-ingresos-al-pa\%C 3\%ADs-por-m\%C3\%A1s-de-86-mil-millones.aspx

92 Colombia, Ley 1556 de 2012, artículos 8-10, por la cual se fomenta el territorio nacional como escenario para el rodaje de obras cinematográficas, 48486 Diario Oficial, 9 de julio de 2012.

93 La silla llena. Van 25 peliculas internacionales en Colombia. Disponible en: http://lasillavacia.com/silla-llena/red-lider/hist oria/van-25-peliculas-internacionales-en-colombia-58897

94 JORGE LUIS ORDELIN-FONT, El contrato de gestión de los representantes de los artistas intérpretes y ejecutantes musicales. Un estudio desde el ordenamiento jurídico cubano, 131 Vniversitas, 391-432 (2015). Disponible en: http://dx.doi.org/10.11144/ Javeriana.vj131.cgra

95 Colombia, Ley 1403 de 2010, Artículo 1, por la cual se adiciona la Ley 23 de 1982, sobre derechos de autor, se establece una remuneración por comunicación pública a los artistas, intérpretes o ejecutantes de obras y grabaciones audiovisuales o "Ley Fanny Mikey", 47.775 Diario Oficial, 19 de julio de 2010.

96 Colombia, Corte Constitucional, Sala Plena, Sentencia C-911 de 2011, Expedientes D-8534, D-8535 y D-8548 (acumulados), magistrado ponente: Mauricio González Cuervo.

97 Actores, Sociedad Colombiana de Gestión, Comunidad Camaleón. Disponible en: http://www.actores.org.co/quienes-so mos

98 A la fecha de remisión de este artículo este tratado no había entrado en vigor, ya que aún no ha sido ratificado por treinta países, incluido Colombia, que es parte firmante.

99 OMPI, Reseña sobre el Tratado de Beijing sobre interpretaciones y ejecuciones audiovisuales (2012). Disponible en: http://w ww.wipo.int/treaties/es/ip/beijing/summary_beijing.html

100 ClARA ROJAS, Proyecto de Ley 218 de 2016. Comisión Primera del Congreso de la República. Disponible en: http://directorescolombia.com.co/wp-content/uploads/2016/09/PL-2016-N218CComision_Primera-LEY_PEPE_SANCHEZ.pdf

101 A la fecha de entrega de este artículo solo hace falta la sanción presidencial de esa ley. 
102 El contenido y estado del proyecto de ley mencionado se encuentra disponible en la Gaceta del Congreso 928 del 27 de octubre de 2016 .

103 Ley de derecho de autor y derechos conexos (Ley de derecho de autor, modificada por la Ley de 4 de abril de 2016), párr. 27. Gesetz über Urheberrecht und verwandte Schutzrechte o Ley de Derecho de Autor y Derechos Conexos. Disponible en: http ://www.wipo.int/wipolex/es/text.jsp?file_id=402669

104 MIGUEL AGUAYO, La Comisión Primera del Senado aprueba la Ley Pepe Sánchez. Instituto Autor, España (2016). Disponible en: http://hemeroteca.institutoautor.org/story/La-Comisin-Primera-del-Senado-de-Colombia-aprueba-la-Ley-Pepe -Snchez-_4553

105 JUAN CAMILO CONTRERAS-JARAMILLO, Análisis de las nuevas prerrogativas del autor sobre las obras derivadas de la suya - a la luz del articulo 21 del TRLPI en España-, 129 Vniversitas, 81-102 (2014). Disponible en: http://dx.doi.org/10.11 144/Javeriana.VJ129.anpa

106 Revive proyecto de Ley Pepe Sánchez, Portafolio (15 de marzo de 2016). Disponible en: http://www.portafolio.co/negocio s/empresas/revive-proyecto-ley-pepe-sanchez-derechos-autor-directores-audiovisuales- 492567

107 Revive proyecto de Ley Pepe Sánchez, Portafolio (15 de marzo de 2016). Disponible en: http://www.portafolio.co/negocio s/empresas/revive-proyecto-ley-pepe-sanchez-derechos-autor-directores-audiovisuales- 492567

108 Ley Pepe Sánchez quedó pendiente de sanción presidencial, Diario el Tiempo (24 de mayo de 2017). Disponible en: http:// www.eltiempo.com/cultura/musica-y-libros/aprueban-ley-pepe-sanchez-que-protege-a-directores-y-guionistas- 91506

109 MANUEL MOYA \& CARLOS BERNAL. Fundamentos semióticospara la investigación jurídica, 58 (Universidad Católica de Colombia, Bogotá, 2017).

110 SANDRA MONTOYA. Politica exterior y diplomacia cultural. Hacia Colombia en posconflicto, 250 (Universidad Católica de Colombia, Bogotá, 2017).

\section{Licencia Creative Commons CC BY 4.0}

Para citar este artículo/To cite this article: Flórez-Acero, Germán Darío, Salazar-Castillo, Sebastián \& Acevedo Pérez, Carlos Ernesto, De la indiferencia pública a la protección de los autores e intérpretes de las producciones de cine en Colombia, a propósito de la ley Pepe Sánchez de 2017, 136 Vniversitas, 1-23. (2018). h ttps://doi.org/10.11144/Javeriana.vj136.dipp 